\title{
A review of the introduced forest pests in Brazil
}

\author{
Guilherme Schnell e Schühli(1), Susete Chiarello Penteado(1), Leonardo Rodrigues Barbosa ${ }^{(1)}$, \\ Wilson Reis Filho(1) and Edson Tadeu lede ${ }^{(1)}$
}

\begin{abstract}
(1)Embrapa Florestas, Estrada da Ribeira, Km 111, Guaraituba, Caixa Postal 319, CEP 83411-000 Colombo, PR, Brazil. E-mail: guilherme.schuhli@embrapa.br, susete.penteado@embrapa.br, leonardo.barbosa@embrapa.br, wilson.reis@colaborador.embrapa.br, edson.iede@embrapa.br
\end{abstract}

\begin{abstract}
Special attention should be given to forest plantings in order to minimize the probability of exotic pest introduction and, consequently, of production losses. The objective of this review was to present, under a historic perspective, the main exotic insects that harm the Brazilian forest sector. Therefore, to better describe the phytosanitary context of introduced forest pests in Brazil, the main information regarding these insects was gathered here. Introduced species and species with a risk of introduction were listed. The following species were registered: 12 exotic introduced species related to eucalyptus, non-quarantine; 9 species related to pine, one quarantine; and 1 species related to teak, quarantine. Overall, the core problems for 57 pest species were addressed, followed by projections on current risks and priorities. Biological control programs and their respective agents were also mentioned. For eucalyptus plantations, the species belonging to the genera Ophelimus and Leptocybe are priorities and should be emphasized. Regarding pine species, the main current concerns are Bursaphelenchus xylophilus (transmitted by species of Monochamus), Rhyacionia frustrana, and Dendroctonus frontalis. Better risk management requires reinforcement of phytosanitary inspections and constant refinement of contingency plans, whose actions include monitoring by visual sampling, employment of sentinel plants, and preventive breeding programs aiming at pest resistance.
\end{abstract}

Index terms: exotic pest, forest pest, forest sector, invasive species, pest resistance, quarantine.

\section{Um artigo de revisão sobre pragas florestais introduzidas no Brasil}

\begin{abstract}
Resumo - Atenção especial deve ser dada a plantações florestais para minimizar a probabilidade de introdução de pragas exóticas e, consequentemente, as perdas de produção. O objetivo deste artigo de revisão foi apresentar, sob uma perspectiva histórica, os principais insetos exóticos que ameaçam o setor florestal brasileiro. Portanto, para melhor descrever o contexto fitossanitário das pragas florestais introduzidas no Brasil, foram compiladas as principais informações sobre esses insetos. Espécies introduzidas e aquelas com risco de introdução foram listadas. Foram contabilizadas: 12 pragas exóticas introduzidas, relacionadas a eucaliptos, sem status quarentenário; 9 espécies relacionadas ao pinus, uma quarentenária; e 1 espécie relacionada à teca, quarentenária. Ao todo, foram abordados os problemas centrais para 57 espécies, acompanhados de projeções sobre risco atual e prioridades. Programas de controle biológico e seus respectivos agentes também foram citados. Para os plantios de eucaliptos, as espécies pertencentes aos gêneros Ophelimus e Leptocybe são prioritárias e devem ser enfatizadas. Quanto às espécies de pinus, as maiores preocupações são Bursaphelenchus xylophilus (transmitida por espécies de Monochamus), Rhyacionia frustrana e Dendroctonus frontalis. Um melhor gerenciamento de risco requer reforço de inspeções fitossanitárias e constante refinamento dos planos de contingência, cujas ações incluem monitoramento por amostragem visual, uso de plantas sentinelas e programas de melhoramento que objetivem a resistência a pragas.
\end{abstract}

Termos para indexação: pragas exóticas, pragas florestais, setor florestal, espécies invasoras, resistência a pragas, quarentenárias.

\section{Introduction}

Brazil displays a relatively small planted forest area of 7.6 million hectares. However, the productivity of this area is notable, contributing with $17 \%$ of the volume of all wood produced worldwide (Indústria Brasileira de Árvores, 2014). In 2006, the planted forest occupied $1.3 \%$ of the country's productive area
(Instituto Brasileiro de Geografia e Estatística, 2007). Nowadays, the forest sector occupies around $3 \%$ of the productive area and is the third in level of importance for Brazilian trade balance. In 2013, Brazilian forest plantations represented a US\$ 27 billion increase in the gross national product (Indústria Brasileira de Árvores, 2014). These results show the strategic value of the planted forest areas to Brazil, indicating 
that protecting this yield and allowing production growth is a necessary challenge. In this scenario, risk and vulnerability analyses are decisive to maintain productivity trends.

Many risks and vulnerabilities are attributed to the increase in the international flow of goods and people, which has allowed the access of exotic pests already present in many parts of the world (Zúbrik et al., 2006). Besides traditional plant propagation material, such as seeds, seedlings, and grafts, exotic insect pests may be also introduced within wood, including timber logs, lumber, and solid wood packing material (Food and Agriculture Organization of the United Nations, 2002). These wooden aids are generally composed by low quality softwoods, which are more vulnerable to insect attack, and also feature large wood volumes, making the inspection service difficult.

Some factors in productive forestry practice are known to predispose plants to risks of insect attack. Generally, the planted forests are composed by large continuous pine or eucalyptus monoculture areas, many of them with a restricted genetic base of species and provenance. Moreover, in eucalyptus plantations, it is common for areas to be derived exclusively from few clones, representing many hectares with a single genotype. This condition contributes to the possible establishment and dispersion of exotic pests. Besides showing reduced genetic variability, which reduces the capacity of resistance to pests, monocultures offer much less resources to the maintenance of natural enemies. Therefore, low environmental resistance favors the introduction and respective population booms of invasive species.

Due to these conditions, special attention should be given to forest plantings in order to minimize the probability of exotic pest introduction and, consequently, of production losses. In 2005, for example, the United States, with a current planted forest area of 25 million hectares, reported an annual loss of US\$ 2 billion, solely attributed to damages from forest pests (Pimentel et al., 2005).

It is important to mention that insect, plant, and fungi biological invasions generally cause substantial ecosystem disturbances that reflect both on economic and on socioeconomic factors (Zúbrik et al., 2006). These disturbances may be considered integrating knowledge regarding pathogens and pests for the current debates over food security and climate changes
(Butterworth et al., 2010). More recently, there have been reports of greater impacts of pests and plant diseases on ecosystem services, either directly, through the destruction of service providers, or indirectly, as a consequence of their management, for example (Cheatham et al., 2009; MacLeod et al., 2010).

To better describe the phytosanitary context of introduced forest pests in Brazil, the main information regarding these insects was gathered here. Since there is no known compilation on the subject, the core problems for each pest, followed by projections on current risks and priorities, were highlighted.

The objective of this review was to present, under a historic perspective, the main exotic insects that harm the Brazilian forest sector.

\section{Introduced quarantine forest pests}

Of the introduced forest pests recorded in Brazil, two species have quarantine status. The first one is the wood wasp Sirex noctilio Fabricius (Hymenoptera: Siricidae), which was first detected in 1988 and is undoubtedly the most important Pinus spp. (Pinaceae) pest in the country (Iede \& Zanetti, 2007). According to Iede \& Zanetti (2007), the affected area was of 4 hundred thousand hectares, causing losses of around U\$S 9 million annually. In an effort to monitor and control S. noctilio populations, a well succeeded national program was started in Brazil, namely "Programa Nacional de Controle à Vespa-da-Madeira". This program has prioritized the biological control, by using the nematode, Deladenus siricidicola and parasitoids which severely reduced $(>70 \%)$ wood wasp incidence levels (Iede \& Zanetti, 2007).

The other quarantine forest pest in Brazil is Sinoxylon unidentatum (Fabricius) (Syn.: S. conigerum Gerstacker) (Coleoptera: Bostrichidae). Bostrichid beetles were first identified in the country in 2001 (Peres Filho et al., 2006). The species damages teak (Tectona grandis L.f., Lamiaceae) plantations (Lunz et al., 2010), which comprise an area of approximately 88 thousand hectares (Indústria Brasileira de Árvores, 2014). Although typical in polyphagous species, the bostrichid $S$. unidentatum also attacks a broad range of other forest trees species, such as tigerwood (Astronium fraxinifolium Schott, Anacardiaceae), balsam tree [Myroxylon balsamum (L.) Harms, Fabaceae] (Lunz et al., 2010), mahogany (Swietenia macrophylla 
King, Meliaceae), and rubber tree [Hevea brasiliensis (Willd. ex A. Juss.) Muell. Arg., Euphorbiaceae] (Peres Filho et al., 2006). The ornamental tree Royal Poinciana [Delonix regia (Bojer) Raf., Fabaceae] is also attacked, as well the mango (Mangifera indica L., Anacardiaceae) and cashew (Anacardium occidentale L., Anacardiaceae) fruit trees (Lunz et al., 2010).

\section{Introduced non-quarantine pests}

\section{Eucalyptus}

The first large-scale eucalyptus plantation in Brazil was established in 1920, and the plantations rose markedly during the 1960s. In 2013, the area planted with eucalyptus reached 5.5 billion hectares (Indústria Brasileira de Árvores, 2014), mostly aimed to produce cellulose (41\%) and firewood (30\%). The main planted species are: Eucalyptus benthamii Maiden \& Cambage (Myrtaceae), Eucalyptus camaldulensis Dehnh, Eucalyptus grandis W.Hill, Eucalyptus pellita F.Muell., Eucalyptus robusta Sm., Eucalyptus saligna Sm., Eucalyptus tereticornis Sm., and Eucalyptus urophylla S.T.Blake (Silva et al., 2012).

The most important borer pest of eucalyptus belongs to the Australian longicorn beetle genus Phoracantha Newman (Coleoptera: Cerambycidae). Among the 40 species within the genus, there are two in Brazil attacking eucalyptus. The first and most cited is Phoracantha semipunctata (Fabricius) (Silva et al., 1968), currently found in all the main eucalyptus producing states (Wilcken et al., 2002). This Cerambycidae is native from Australia but was found in Brazil in Corymbia citriodora (Hook) Hill \& Jonhson (Myrtaceae). The most susceptible species to the borer worldwide are: E. camaldulensis, Eucalyptus globulus Labill., Eucalyptus gomphocephala DC., and Eucalyptus viminalis Hook. (Berti Filho et al., 1995). The second species registered is Phoracantha recurva Newman. In Brazil, the species was found attacking Eucalyptus citriodora Hook., Eucalyptus cloeziana F.Muell., and E. camaldulensis (Wilcken et al., 2002).

Two species of weevil beetles (Coleoptera, Curculionidae), belonging to the genus Gonipterus Schoenherr, were also introduced in Brazil. The genus contains about 20 described species, most of them occurring in Australia (Mapondera et al., 2012). It should be noted that, outside of their native range, adults and larvae feeding on leaves cause severe damages to eucalyptus. The defoliator species Gonipterus pulverulentus Lea, 1897 and Gonipterus platensis (Marelli, 1926) (Coleoptera: Curculionidae) compose the first formal record of an exotic forest pest in Brazil (Iede, 2005).

Gonipterus scutellatus Gyllenhal, 1833 is recognized as a complex taxonomic group. According to some authors, it is a cluster of cryptic species, which has led to many contrasting taxonomic propositions. Gonipterus platensis (Marelli, 1926), for example, was commonly presented as a synonym of $G$. scutellatus (Rosado-Neto \& Marques, 1996). However, recently, a molecular study has shed some light on the identity of the species belonging to this group, showing that some of them have been misinterpreted. This is the case of G. pulverulentus, which had been previously misidentified in eastern South America as Gonipterus gibberus Gyllenhal, 1833. In New Zealand, America, and Western Europe, it was found that the reported pest species was actually $G$. platensis, instead of G. scutellatus (Mapondera et al., 2012); both species were dispersed with the host plant (eucalyptus).

The susceptibility of Eucalyptus species to G. pulverulentus and G. platensis attack differs from species to species. The most susceptible ones are: E. camaldulensis, E. globulus, Eucalyptus maidenii F.Muell., Eucalyptus punctata DC., E. robusta, Eucalyptus smithii R.T.Baker, and E. viminalis (Griffith, 1959).

The threat of Gonipterus spp. to eucalyptus plantations was first noticed when a large number of this species was found in E. globulus plantations in Australia (Mapondera et al., 2012). The introduction of E. globulus from the Tasmanian region in many parts of the world may have been responsible for the entry of the pest in South America (Mapondera et al., 2012).

Another concern regarding eucalyptus plantations are some Psylloidea (Hemiptera) species, since many of them naturally feed on eucalyptus in Australia (Kurylo et al., 2010). Some of these species have already been reported in Brazil and all of them belong to Aphalaridae (Hemiptera: Psylloidea) (Burckhardt \& Ouvrard, 2012). Among them, is the species Ctenarytaina eucalypti (Maskell), also known as blue gum psyllid. This species is considered the most widespread and harmful to E. globulus plantations. In Brazil, this pest had already been observed in Eucalyptus dunnii 
Maiden seedlings and it was also found causing damage to E. globulus plantations (Kurylo et al., 2010). These damages are described mostly as injuries caused on leaves and shoots of E. dunnii in the nursery.

Another species of Ctenarytaina (Hemiptera: Psylloidea) is able to attack drought-affected shoots of E. grandis. The psyllid Ctenarytaina spatulata Taylor (Hemiptera, Psyllidae) was first detected in Brazil in 1994 (Queiroz et al., 2010). The insect originates from Australia but has spread to other parts of the world. Ctenarytaina spatulata has been observed occurring on many different species of eucalyptus, such as E. camaldulensis, E. globulus, E. grandis, Eucalyptus parvifolia Cambage, and E. viminalis. The adults and nymphs of this psyllid feed on plant sap and are mainly found on mature shoots, especially in the apical part of the tree, in contrast with C. eucalypti introduced in 1996, which prefers young shoots. Attacked shoots show small necrotic lesions, proliferation of lateral shoots, and leaf distortions. In addition, C. spatulata produces large amounts of honeydew on which sooty molds can develop (Santana \& Zanol, 2005). In Brazil, it is suspected that $C$. spatulata could be involved in a growth disorder of $E$. grandis called "seca dos ponteiros", characterized by lateral sprouting, foliar spots, cankers at petiole insertion, and tip dieback. The main parasitoid of this pest, Psyllaephagus pilosus (Noyes, 1988), was introduced accidentally in Brazil and probably restricted the expansion of the pest populations (Queiroz et al., 2012).

Another Australian psyllid genus, Blastopsylla occidentalis Taylor (Hemiptera: Psylloidea), is also known as a eucalyptus psyllid. The species was first described in Australia. In Brazil, B. occidentalis was found feeding on E. grandis and Eucalyptus urophylla S.T.Blake (both are its main hosts), Eucalyptus blakelyi Maiden, Eucalyptus brassiana S.T.Blake, Eucalyptus forrestiana Diels, E. globulus, E. gomphocephala, Eucalyptus microneura Maiden \& Blakely, Eucalyptus microtheca F.Muell., Eucalyptus nicholii Maiden \& Blakely, Eucalyptus nicholsii, Eucalyptus oleosa F.Muell. ex Miq., Eucalyptus rudis Endl., E. saligna, Eucalyptus spathulata Hook., and Eucalyptus tereticornis Sm. (Queiroz et al., 2012).

The red gum lerp psyllid Glycaspis brimblecombei Moore, 1964 (Hemiptera: Aphalaridae) is another exotic species associated to eucalyptus. It is original from Australia and was detected in Brazil in 2003.
The nymphs are covered with a small starch-based protective structure called lerp. These sap-sucking insects cause leaf discoloration, photosynthetic area reduction, and breakdown of tips, and, therefore, compromise tree growth (Wilcken et al., 2015). The red gum lerp uses many Eucalyptus species as hosts, showing preference for E. camaldulensis and E. tereticornis. However, it may also be associated to E. blakelyi, E. brassiana, Eucalyptus bridgesiana R.T.Baker, Eucalyptus camphora R.T.Baker, Eucalyptus dealbata Schauer, Eucalyptus diversicolor F.Muell, E. globulus, Eucalyptus mannifera Mudie, Eucalyptus nitens Maiden, and Eucalyptus sideroxylon Woolls (Hollis, 2004). Aiming to control the red gum lerp psyllid in Brazil, a biological control program was initiated to introduce the egg parasitoid Psyllaephagus bliteus Riek, 1962 (Wilcken et al., 2010a).

Of the six species of gall-making wasps that established themselves on eucalypts outside Australia, two have already been reported in Brazilian eucalypts plantations. The first of them is Epichrysocharis burwelli Schauff (Hymenoptera: Eulophidae). This wasp was first noted in 2003 attacking C. citriodora, and it was estimated that the species may have caused losses from 30 to $80 \%$ in the essential oil production of C. citriodora (Santana \& Anjos, 2007).

The second gall-making wasp is Leptocybe invasa Fisher \& La Salle, 2004 (Hymenoptera: Eulophidae), supposedly originated from Australia. It was first observed in Israel in 2000 and has since spread rapidly (Thu et al., 2009). This wasp is a devastating pest of eucalyptus plantations, woodlots, and urban trees (Thu et al., 2009). Leptocybe invasa displays thelytokous reproduction, forming typical bump-shaped galls on the leaf midribs, petioles, and stems of new growth of several Eucalyptus species (Garlet et al., 2013). It was registered in Brazil in 2008, followed by records in Argentina in 2009 and in Uruguay in 2011 (Wilcken \& Berti Filho, 2008; Aquino et al., 2011). In Brazil, the wasp is already established in several states, such as Bahia, São Paulo, Minas Gerais, Mato Grosso do Sul, Tocantins, Maranhão, Pernambuco, Paraná, Santa Catarina, and Rio Grande do Sul (Costa et al., 2008; Wilcken et al., 2010b, 2012; Garlet et al., 2013; Rinaldi et al., 2013). A biological control program is in progress, aiming to introduce the Selitrichodes neseri Kelly \& La Salle parasitoid from South Africa. This parasitoid was imported by the Costa Lima quarantine 
laboratory of Embrapa Meio Ambiente, located in the municipality of Jaguariúna, in the state of São Paulo, Brazil; and the multiplication of the species is being conducted at Universidade Estadual Paulista Júlio de Mesquita (Unesp), located in the municipality of Botucatu, also in the state of São Paulo.

A wide sample of Eucalyptus species was tested in Vietnam aiming to evaluate the most susceptible ones. The study concluded that L. invasa is capable of feeding and forming galls on 13 species of Eucalyptus and on 1 species of Corymbia (Thu et al., 2009). The most threatened species is E. camaldulensis (Garlet et al., 2013), followed by E. grandis, E. tereticornis (all three susceptible to severe damage), and E. saligna (susceptible to medium damage) (Thu et al., 2009). The last three species are largely cultivated in Brazil, and the mentioned study made it possible to rank the vulnerability of the Brazilian commercial species of eucalyptus to the insect.

The bronze bug Thaumastocoris peregrinus Carpintero \& Dellapé, a small sap-feeding Hemipteran insect of the family Thaumastocoridae (Carpintero \& Dellapé, 2006; Laudonia \& Sasso, 2012), is a recently introduced pest of eucalyptus, which was reported in Brazil in 2008 (Wilcken et al., 2010b). In South America, it was previously found in Argentina in 2005, and, since then, the insect populations have grown explosively (Nadel et al., 2010).

This species reached an almost ubiquitous distribution, including regions as Australia (Noack \& Rose, 2007), South America (Wilcken et al., 2010b), and South Africa (Giliomee, 2011). Severe infestations decrease host photosynthetic rates, causing partial or total defoliation, even killing the tree in some cases (Jacobs \& Neser, 2005).

In South Africa, the bronze bug attacked 26 Eucalyptus species (Nadel et al., 2010). In Brazil, the occurrence of $T$. peregrinus was documented by Wilcken et al. (2010b). It concerns Brazilian eucalyptus production, especially of: E. camaldulensis, E. tereticornis, E. urophylla, E. viminalis, and different hybrid clones of E. grandis $\mathrm{x}$ E. urophylla, E. grandis $\mathrm{x}$ E. camaldulensis, and E. urophylla $\mathrm{x}$ E. camaldulensis (Wilcken et al., 2010b). Therefore, a promising biological control program is in progress, based on the parasitoid Cleruchoides noackae Lin \& Huber (Hymenoptera: Mymaridae), which parasites on eggs of the bronze bug (Lin et al., 2007). This hymenopteran was introduced in Brazil in 2012 under a cooperative effort, involving Instituto de Pesquisas e Estudos Florestais, Unesp, Empresa Brasileira de Pesquisa Agropecuária, and companies from the forestry sector (Barbosa et al., 2014). The parasitoid was settled and already confirmed in many states, and the parasitism rate is $25-50 \%$ (Wilcken et al., 2015).

\section{Pine}

In the last decades, there has been a fast increment in the areas reforested with species of Pinus in Brazil, introduced mainly from the United States and Australia (Lázzari et al., 2004). The Pinus species planted in Brazil account for $20.7 \%$ of all area planted with trees (Indústria Brasileira de Árvores, 2014). The main planted species are loblolly pine (Pinus taeda L.) and slash pine (Pinus elliottii Englem.) (Lázzari et al., 2004).

Since 1996, some species belonging to the giant conifer aphid, of the genus Cinara (Hemiptera: Aphididae), were found in the country, attacking loblolly and slash pine plantations. The genus Cinara is composed of about 200 species that occur on conifers distributed around the world (Blackman $\&$ Eastop, 1984). The attacked trees show retarded development, needle shedding, branch twisting, and abundant production of honeydew that favors sooty mold development, affecting photosynthesis. Lázzari et al. (2004) listed the following species occurring in Brazil: Cinara maritimae (Dufour, 1833); Cinara piniformosana (Takahashi, 1923); Cinara tujafilina (Del Guercio, 1909); Cinara fresai Blanchard, 1939; Cinara pinivora (Wilson, 1919); and Cinara atlantica (Wilson, 1919).

Within the cited species, C. pinivora and C. atlantica are of major concern regarding the Brazilian P. taeda and $P$. elliottii plantations. The species $C$. pinivora is native from North America and was introduced accidentally in Australia, Argentina, Uruguay, and Brazil, whereas $C$. atlantica is the most important species in the south of the United States. A biological control program was established in Brazil by Embrapa Florestas in cooperation with three other institutions - Fundo Nacional de Controle da Vespa da Madeira, Universidade Federal do Paraná, and University of Illinois Urbana-Champaign - during 2001 and 2004 (Penteado et al., 2004). Aiming to reduce the damage caused by the giant conifer aphid, the control program imported the parasitoid Xenostigmus bifasciatus 
(Hymenoptera: Braconidae) and suggested silvicultural measures resulting in an effective control of Cinara species. In Brazil, the field release of this parasitoid was done from 2002 to 2004. Dispersion and establishment were confirmed in all target areas, and, in some aphid populations, the parasitism rate reached about 100\% (Vilela \& Zucchi, 2015).

Another aphid, known as the Monterey pine aphid [Essigella californica (Essig, 1909) (Hemiptera: Aphididae)], also attacks Pinus species (Iede, 2005). It is native from the United States and was imported to Brazil, where attacks to P. elliottii and Pinus patula Schltdl. \& Cham. have been registered.

Eulachnus rileyi (Williams, 1911) (Hemiptera: Aphididae) is native from the United States (Palmer, 1952) and was reported as an exotic pest in Brazil in 1970, attacking Pinus species. This pest may cause chlorosis and even needle loss.

The hemipteran Pineus boerneri Annand, 1928 (Adelgidae), or the pine wooly aphid, is the first record of an Adelgidae species in Brazil. It was found on P. taeda, P. elliottii, and Pinus caribaea Morelet (Lazzari \& Cardoso, 2011). The pine wooly aphid is distributed in North America, Europe, New Zealand, Australia, Chile, South Africa, Malaysia, Taiwan, Kenya, Malawi, and Pakistan (Blackman \& Eastop, 1994), infesting over 40 species of Pinus.

The borer Pissodes castaneus (De Geer, 1775) (Coleoptera: Curculionidae), or banded pine weevil, was first registered in Brazil in 2000. This Curculionidae's larval galleries prevent the circulation of sap, causing slow desiccation, which is manifested by wilting and general yellowing and browning of the needles, and, occasionally, by the death of the tree (Cheraghian, 2013). This weevil is usually a secondary pest of conifers that have been weakened in some way, and is often associated with or in succession to another pest (Cheraghian, 2013).

\section{Absent quarantine pests in Brazil}

Brazil is one of the signatories of the International Plant Protection Convention, and, therefore, adopts the recommendations and directives contained in the International Standards for Phytosanitary Measures No. 11 (Lopian, 2005). The pest risk analysis procedure made it possible to list the pests, including those related to planted forest.
The list for absent quarantine forest pests in Brazil was published by Ministério da Agricultura, Pecuária e Abastecimento (Brasil, 2015). Part of the invasive quarantine pest species that threaten eucalyptus are of the lepidopteran Cossidae species, that is, Cossus cossus (Linnaeus, 1758), Zeuzera pyrina (Linnaeus, 1761), and Chilecomadia valdiviana (Philippi, 1860).

Other invasive quarantine pest species that threaten Pinus are the hymenopterans Megastigmus spp. (Torymidae) and Neodiprion spp. (Diprionidae). Several coleopteran pests are also related to Pinus species, such as: the bostrichids Heterobostrychus aequalis (Waterhouse, 1884) and Sinoxylon spp.; the cerambycids Monochamus spp., Anoplophora glabripennis (Motschulsky, 1853), Callidiellum rufipenne (Motschulsky, 1860), and Tetropium fuscum (Fabricius, 1787); the curculionids Hylobius abietis (Linnaeus, 1758), Hylobius pales (Herbst, 1797), Dendroctonus spp., Ips spp., and Tomicus piniperda (Linnaeus, 1958); the lepidopterans Hyphantria cunea (Drury, 1773) (Arctiidae), Lymantria monacha (Linnaeus, 1758) and Lymantria dispar (Linnaeus, 1758) (both Lymantriidae), Choristoneura spp. (Tortricidae), and Thaumetopoea pityocampa (Denis $\&$ Schiffermüller, 1776) (Thaumetopoeidae).

\section{Potentially quarantine pests}

\section{Eucalyptus}

The eucalyptus-defoliating tortoise beetles Trachymela tincticollis (Blackburn) and Trachymela sloanei (Chrysomelidae: Chrysomelini: Paropsina) feed on a wide variety of eucalyptus. Trachymela tincticollis was discovered initially in Cape Town, South Africa, in 1982, whereas T. sloanei was detected in California, in the United States, in 1998, and spread to vicinities. Both species produce visible damages (semicircular holes or irregular notches along the edges of the leaves), and the larvae secrete irritants, representing a potential hazard to outdoor activities. It should be noted that $T$. sloanei is not normally a pest in Australia, presumably because of the natural enemies that attack several life stages of the beetle. However, when this species was accidentally introduced to New Zealand in 1976, it caused extensive defoliation and tree damage (Millar et al., 2000) before being brought under control with natural enemies. Documented cases of this pest and related Australian defoliating 
beetles have shown that, if left unchecked, populations can explode, causing severe damage to eucalyptus plantations (Selman, 1994).

Two gall-making wasp species, Ophelimus eucalypti (Gahan, 1922) and Ophelimus maskelli (Ashmead, 1900) (Hymenoptera, Eulophidae), may be stated as quarantine pests related to eucalyptus. Ophelimus is a large genus with nearly 50 species (Withers et al., 2000) but is still poorly known regarding its biology and systematics. Ophelimus species develop by producing galls on many Eucalyptus species. Since taxonomic keys for the genus are still inexistent for proper identification (Protasov et al., 2007), misidentifications are common, as in the case of $O$. maskelli samples captured in the Mediterranean that were erroneously identified as O. eucalypti (Protasov et al., 2007).

Another concern regarding eucalyptus pests are the Chrysomelidae (Coleoptera) Chrysophtharta m-fuscum (Boheman), also known as the southern eucalyptus leaf beetle, and Chrysophtharta bimaculata (Olivier), also known as the Tasmanian eucalyptus leaf beetle. Both species are regulated pests in New Zealand, associated with bark and potentially with lumber. Despite being native of Tasmania and Victoria, both in Australia, these species are considered as pests only in Tasmania (MacLeod, 2007). They occur naturally in many Eucalyptus species, including some with high economical interest in Brazil, such as E. globulus, E. camaldulensis, C. citriodora, E. grandis, and E. viminalis.

These Chrysophtharta species could cross the borders to other countries in timber or wood chips from native areas in Australia. Another possibility is the transport of these insects hidden in the foliage of ornamental eucalyptus or inside Australian ornamental ferns, such as Dicksonia antarctica Labill.

Eucalyptolyma maidenii (Hymenoptera: Aphalaridae), also known as the spotted gum lerp psyllid, is another eucalyptus pest, originally from Southeast Australia. The species shows affinities with the genus Corymbia, specifically with the ornamental species C. citriodora and Corymbia maculate (Hook.) K.D.Hill \& L.A.S.Johnson. These lerp psyllids produce copious amounts of honeydew, which stain the ground beneath the trees. A blackish sooty mold grows on the honeydew-covered surfaces (Garrison, 2001). Heavy infestations cause leaf drop, may weaken trees, and may increase tree susceptibility to adverse cultural and climatic conditions, including drought. However, these effects were not economically evaluated within the Brazilian forestry production.

\section{Pine}

Some pine moth caterpillars from the genus Dendrolimus (Lepidoptera: Lasiocampidae) turned out to be a concern due to the damages they cause as defoliators. In its New Pest Response Guidelines, the United States Department of Agriculture (2012) highlighted four species within Dendrolimus: Dendrolimus pini (L.) or the pine-tree lappet moth, Dendrolimus punctatus (Walker) or the Masson pine caterpillar, Dendrolimus sibiricus Tschetverikov or the Siberian silk moth, and Dendrolimus superans (Butler) or the Sakhalin silk moth; however, according to some taxonomists, these two last species are a single one, i.e., D. superans, with two subspecies (Gonipterus..., 2005).

All these species are native from Europe and Asia. Although the main host for D. punctatus, the pine Pinus massoniana (Lamb.), is not found in Brazil, several alternate hosts are largely used in plantation forestry in the country, such as P. elliotii and P. taeda (Zhang et al., 2003). It should be noted that $P$. taeda is also a secondary host to $D$. sibiricus and $D$. superans (United States Department of Agriculture, 2012).

Among the potential quarantine pests, some species belong to the anobiid beetles from the genus Ernobius, with special mention to Ernobius pini (Sturm, 1837). These insects may reach new countries associated with $\log$ s and chips of Australian Pinus, since they are typical Pinus borers (Kliejunas et al., 2003).

The cone worm Dioryctria abietella Denis \& Schiff. (Lepidoptera: Pyralidae) infests cones and seeds of spruce (Picea spp.). It also seriously damages some conifer species within the genus Pinus, Cedrus, Abies, and Picea. Some other species, such as Dioryctria horneana (Dyar, 1919) and Dioryctria clarioralis (Walker, 1863), are known to attack Pinus caribaea Morelet (Nair, 2007), a conifer that has great importance for forestry in southeast Brazil.

\section{Concluding remarks}

The rising trends of the Brazilian forestry sector demand special attention to pest risks. The country shows competency by acting properly in many cases of exotic pest species. These actions involve several actors, such as governmental research agencies, 
universities, forestry sector companies, and also the third sector. Technology transfer has a key role in the process and is substantial in reaching producers. Based on this collaborative approach, many control programs in Brazil are effective in controlling Sirex noctilio, Cinara atlantica, Glycaspis brimblecombei, Thaumastocoris peregrinus, and, most recently, Leptocybe invasa.

It is perceptible that species not considered pests in their natural distribution may turn out to be a hazardous menace when introduced in a foreign environment. This is the reason why efforts in watching out for quarantine pests should be kept and also extended, in order to detect other indications of possible quarantine pests. Keeping continuous phytosanitary surveillance measures, such as pest risk analyses, is necessary to protect the Brazilian forest production and the viability of further international trades.

In this context, better risk management requires reinforcement of phytosanitary inspections and constant refinement of contingency plans, whose actions include monitoring by visual sampling, employment of sentinel plants, and preventive breeding programs aiming at pest resistance.

\section{References}

AQUINO, D.A.; BOTTO, E.N.; LOIÁCONO, M.S.; PATHAUER, P. "Avispa de la agalla del eucalipto", Leptocybe invasa Fischer \& Lasalle (Hymenoptera: Eulophidae: Tetrastichinae), en Argentina. Revista de Investigaciones Agropecuarias, v.37, p.159-164, 2011.

BERTI FILHO, E.; CERIGNONI, J.A.; NOGUEIRA, JÚNIOR, C.S. Phoracantha semipunctata (Fabricius (Coleoptera, Cerambycidae) broca de Eucalyptus spp., nativa da Austrália, já ocorre no estado de São Paulo. Notícias IPEF, v.48/49, p.142-143, 1995.

BARBOSA, L.R.; BELTRAMIN, F.S.; RODRIGUES, A.P.; CROSA, G.M.; WILCKEN, C.F. Improving mass rearing techniques for Cleruchoides noackae (Hymenoptera: Mymaridae). International Forestry Review, v.16, p.476, 2014.

BLACKMAN, R.L.; EASTOP, V.F. Aphids on the world's crops: an identification and information guide. Chichester: J. Wiley, 1984.

BLACKMAN, R.L.; EASTOP, V.F. Aphids on the world's trees: an identification and information guide. Wallingford: $\mathrm{CAB}$ International, 1994.

BRASIL.MinistériodaAgricultura.Listadepragasquarentenárias ausentes. Disponível em: < http:/www.agricultura.gov.br/arq editor/file/vegetal/Importacao/Arquivos\%20de\%20Quarentenas_ Pragas/Listas\%20de\%20Pragas\%20Quarenten\%C3\%A1 rias\%20 Ausentes\%20-\%20A1.pdf>. Acesso em: 20 ago. 2015.
BURCKHARDT, D.; OUVRARD, D. A revised classification of the jumping plant-lice (Hemiptera: Psylloidea). Zootaxa, v.3509, p.1-34, 2012. DOI: 10.11646/zootaxa.3509.1.1.

BUTTERWORTH, M.H.; SEMENOV, M.A.; BARNES, A.; MORAN, D.; WEST, J.S.; FITT, B.D.L. North-South divide: contrasting impacts of climate change on crop yields in Scotland and England. Journal of the Royal Society Interface, v.7, p.123-130, 2010. DOI: 10.1098/rsif.2009.0111.

CARPINTERO, D.L.; DELLAPÉ, P.M. A new species of Thaumastocoris kirkaldy from Argentina (Heteroptera: Thaumastocoridae: Thaumastocorinae). Zootaxa, v.1228, p.61-68, 2006.

CHEATHAM, M.R.; ROUSE, M.N.; ESKER, P.D.; IGNACIO, S.; PRADEL, W.; RAYMUNDO, R.; SPARKS, A.H.; FORBES, G.A.; GORDON, T.E.; GARRETT, K.A. Beyond yield: plant disease in the context of ecosystem services. Phytopathology, v.99, p.1228-1236, 2009. DOI: 10.1094/PHYTO-99-11-1228.

CHERAGHIAN, A. (Ed.). Banded pine weevil Pissodes castaneus (DeGeer, 1775) Coleoptera: Curculionidae. [Iran]: Bureau of Plant Pest Surveillance and Pest Risk Analysis, 2013.

COSTA, E.C.; D'AVILA, M.; CANTARELLI, E.B.; MURARI, A.B.; MANZONI, C.G. Entomologia Florestal. Santa Maria: Ed. da UFSM, 2008.

FOOD AND AGRICULTURE ORGANIZATION OF THE UNITED NATIONS. International standards for phytossanitary measures: guidelines for regulating wood packing material in the international trade. Rome: FAO, 2002. (FAO. ISPM, 15).

GARLET, J.; COSTA, E.C.; BOSCARDIN, J.; DEPONTI, G.; SHWENGBER, C.R.; MACHADO, L.M. Leptocybe invasa em Eucalyptus sp. no estado do Rio Grande do Sul, Brasil. Ciência Rural, v.43, p.2175-2177, 2013. DOI: 10.1590/ S0103-84782013001200009.

GARRISON, W. New agricultural pest for Southern California: Spotted Gum Lerp Psyllid, Eucalyptolyma maideni. San Diego: San Diego County Agricultural Commissioner's office, 2001. Available at: <http://www.sandiegocounty.gov/reusable_ components/images/awm/Docs/ipd_spottedpsyllid.pdf $>$. Acessed on: 28 ago. 2015.

GILIOMEE, J. Recent establishment of many alien insects in South Africa: a cause for concern. African Entomology, v.19, p.151-155, 2011. DOI: 10.4001/003.019.0105.

GRIFFITH, A.L. A list of Eucalyptus species known to be attacked by the snout beetle Gonipterus scutellatus. Empire Forestry Review, v.38, p.200-201, 1959.

GONIPTERUS gibberus and Gonipterus scutellatus. EPPO Bulletin, v.35, p.368-370, 2005.

HOLLIS, D. Australian Psylloidea: jumping plantlice and lerp insects. Canberra: Australian Biological Resources Study, 2004.

IEDE, E.T. Importância das pragas quarentenárias florestais no comércio internacional: estratégias e alternativas para o Brasil. Colombo: Embrapa Florestas, 2005. (Embrapa Florestas. Boletim de pesquisa e desenvolvimento, 22). 
IEDE, E.T.; ZANETTI, R. Ocorrência e recomendações para o manejo de Sirex noctilio Fabricius (Hymenoptera, Siricidae) em plantios de Pinus patula (Pinaceae) em Minas Gerais, Brasil. Revista Brasileira de Entomologia, v.51, p.529-531, 2007. DOI: 10.1590/S0085-56262007000400023.

INDÚSTRIA BRASILEIRA DE ÁRVORES. Indústria Brasileira de Árvores. [Brasília]: Iba, 2014. Disponível em: <http://www.iba. org/shared/iba_2014_pt.pdf $>$. Acesso em: 28 ago. 2015.

INSTITUTO BRASILEIRO DE GEOGRAFIA E ESTATÍSTICA. Censo Agropecuário 1920/2006. Rio de Janeiro: IBGE, 2007.

JACOBS, D.H.; NESER, S. Thaumastocoris australicus Kirkaldy (Heteroptera: Thaumastocoridae): a new insect arrival in South Africa, damaging to Eucalyptus trees. South African Journal of Science, v.101, p.233-236, 2005.

KLIEJUNAS, J.T.; BURDSALL JR., H.H.; DENITTO, G.A.; EGLITIS, A.; HAUGEN, D.A.; HAVERTY, M.I.; MICALES, J.A.; TKACZ, B.M.; POWELL, M.R. Pest risk assessment of the importation into the United States of unprocessed logs and chips of eighteen Eucalypt species from Australia. Madison: U.S. Department of Agriculture, Forest Service, Forest Products Laboratory, 2003.

KURYLO, C.L.; GARCIA, M.S.; COSTA, V.A.; TIBOLA, C.; RAMIRO, G.A; FINKENAUER, E. Ocorrência de Ctenarytaina eucalypti (Maskell) (Hemiptera: Psyllidae) e seu inimigo natural Psyllaephagus pilosus Noyes (Hymenoptera: Encyrtidae) em Eucalyptus globulus no Rio Grande do Sul. Neotropical Entomology, v.39, p.671-673, 2010. DOI: 10.1590/ S1519-566X2010000400031.

LAUDONIA, S.; SASSO, R. First record of the bronze bug, Thaumastocoris peregrinus Carpintero \& Dellapé (Heteroptera: Thaumastocoridae), a new exotic pest of Eucalyptus trees in Italy. 2012. Available at: <http://www.eppo.int/QUARANTINE/ special_topics/Thaumastocoris_peregrinus/Thaumastocoris_ peregrinus.htm $>$. Accessed on: 28 ago. 2015.

LÁZZARI, F.N.; TRENTINI, R.F.R.; CARVALHO, R.C.Z. de. Occurrence of Cinara spp. (Hemiptera, Aphididae) on Pinus spp. (Pinaceae), in the county of Lages-SC, Brazil. Revista Brasileira de Entomologia, v.48, p.287-289, 2004. DOI: 10.1590/ S0085-56262004000200019.

LAZZARI, S.M.N.; CARDOSO, J.T. Pineus boerneri Annand, 1928 (Hemiptera, Adelgidae) - a new species to Brazil: morphology of eggs, nymphs and adults. Revista Brasileira de Entomologia, v.55, p.459-466, 2011. DOI: 10.1590/S0085-56262011000400001.

LIN, N.-Q.; HUBER, J.T.; LA SALLE, J. The Australian Genera of Mymaridae (Hymenoptera: Chalcidoidea). Zootaxa, v.1596, p.1-111, 2007.

LOPIAN, R. The International Plant Protection Convention and invasive alien species. In: SECRETARIAT OF THE INTERNATIONAL PLANT PROTECTION CONVENTION. Identification of risks and management of invasive alien species using the IPPC framework: proceedings of a workshop in Braunschweig, Germany 22-26 September 2003. Rome: FAO, 2005. p.6-16.

LUNZ, A.M.; PERES FILHO, O.; CARDOSO, J.E.F.; SILVA, J.L.S. da. Monitoramento de Sinoxylon conigerum (Gerstäcker,
1885) (Coleoptera: Bostrichidae) em Madeira de Teca (Tectona grandis L.f.) no estado do Pará. Belém: Embrapa Amazônia Oriental, 2010. 7p. (Embrapa Amazônia Oriental. Comunicado técnico, 224).

MACLEOD, A. CSL pest risk analysis for Ophelimus maskelli. York: Central Science Laboratories, 2007.

MACLEOD, A.; PAUTASSO, M.; JEGER, M.J.; HAINES-YOUNG, R. Evolution of the international regulation of plant pests and challenges for future plant health. Food Security, v.2, p.49-70, 2010. DOI: 10.1007/s12571-010-0054-7.

MAPONDERA, T.S.; BURGESS, T.; MATSUKI, M.; OBERPRIELER, R.G. Identification and molecular phylogenetics of the cryptic species of the Gonipterus scutellatus complex (Coleoptera: Curculionidae: Gonipterini). Australian Journal of Entomology, v.51, p.175-188, 2012. DOI: 10.1111/j.1440-6055.2 011.00853.x.

MILLAR, J.G.; PAINE, T.D.; HODDLE, M. Biological control of a newly introduced pest, the eucalyptus tortoise beetle, Trachymela sloanei. [California: University of California], 2000. 7p. (EJ Slosson Endowment for Ornamental Horticulture. Slosson Report 1999-2000).

NADEL, R.L.; SLIPPERS, B.; SCHOLES, M.C.; LAWSON, S.A.; NOACK, A.E.; WILCKEN, C.F.; WINGFIELD, M.J. DNA bar-coding reveals source and patterns of Thaumastocoris peregrinus invasions in South Africa and South America. Biological Invasions, v.12, p.1067-1077, 2010. DOI: 10.1007/ s10530-009-9524-2.

NAIR, K.S.S. Tropical forest insect pests: ecology, impact and management. Cambridge: Cambridge University Press, 2007. DOI: 10.1017/CBO9780511542695.

NOACK, A.E.; ROSE, H.A. Life-history of Thaumastocoris peregrinus and Thaumastocoris sp. in the laboratory with some observations on behaviour. General and Applied Entomology, v.36, p.27-33, 2007.

PALMER, M.A. Aphids of the Rocky Mountain Region. Denver: The Thomas Say Foundation, 1952.

PENTEADO, S. do R.C.; REIS FILHO, W.; IEDE, E.T. Os pulgões gigantes do pinus, Cinara pinivora e Cinara atlantica, no Brasil.Colombo: Embrapa Florestas, 2004. (Embrapa Florestas. Circular técnica, 87).

PERES FILHO, O.; TEIXEIRA, E.P.; BEZERRA, M.L.M.; DORVAL, A.; BERTI FILHO, E. First record of Sinoxylon conigerum Gerstäcker (Coleoptera: Bostrichidae) in Brazil. Neotropical Entomology, v.35, p.712-713, 2006. DOI: 10.1590/ S1519-566X2006000500023.

PIMENTEL, D.; ZUNIGA, R.; MORRISON, D. Update on the environmental and economic costs associated with alien-invasive species in the United States. Ecological Economics, v.52, p.273-288, 2005. DOI: 10.1016/j.ecolecon.2004.10.002.

PROTASOV, A.; BLUMBERG, D.; BRAND, D.; LA SALLE, J.; MENDEL, Z. Biological control of the eucalyptus gall wasp Ophelimus maskelli (Ashmead): taxonomy and biology of the parasitoid species Closterocerus chamaeleon (Girault), with 
information on its establishment in Israel. Biological Control, v.42, p.196-206, 2007. DOI: 10.1016/j.biocontrol.2007.05.002.

QUEIROZ, D.L. de; BURCKHARDT, D.; MAJER, J. Integrated pest management of eucalypt psyllids (Insecta, Hemiptera, Psylloidea). In: LARRAMENDI, M.L.; SOLONESKI, S. (Ed.). Integrated pest management and pest control: current and future tactics. Rijeka: InTech, 2012. p.385-412. DOI: 10.5772/32631.

QUEIROZ, D.L. de; ZANOL, K.M.R.; OLIVEIRA, E.B.; ANJOS, N. dos; MAJER, J. Feeding and oviposition preferences of Ctenarytaina spatulata Taylor (Hemiptera, Psyllidae) for Eucalyptus spp. and other Myrtaceae in Brazil. Revista Brasileira de Entomologia, v.54, p.149-153, 2010. DOI: 10.1590/ S0085-56262010000100023.

RINALDI, D.A.M. da F.; BARBOSA, L.R.; WILCKEN, C.F.; ZACHÉ, B.; ARAÚJO, M.M.; CARVALHO, R.C.Z. de. Ocorrência de Leptocybe invasa (Hymenoptera: Eulophidae) em mudas de eucalipto no estado do Paraná. Pesquisa Florestal Brasileira, v.33, p.327-330, 2013. DOI: 10.4336/2013.pfb.33.75.400.

ROSADO-NETO, G.H.; MARQUES, M.I. Características do adulto, genitália e formas imaturas de Gonipterus gibberus Boisduval e G. scutellatus Gyllenhal (Coleoptera, Curculionidae). Revista Brasileira de Zoologia, v.13, p.77-90, 1996. DOI: 10.1590/S0101-81751996000100007.

SANTANA, D.L. de Q.; ZANOL, K.M.R. Morfologia externa das ninfas e adultos de Ctenarytaina spatulata Taylor (Hemiptera, Psyllidae). Revista Brasileira de Entomologia, v.49, p.340-346, 2005. DOI: 10.1590/S0085-56262005000300003.

SANTANA, D.L.Q.; ANJOS, N. dos. Microvespa-do-eucalipto-citriodora (Corymbia citriodora) Epichrysocharis burwelli Schauff (Hymenoptera: Eulophidae). Colombo: Embrapa Florestas, 2007. 4p. (Embrapa Florestas. Comunicado técnico, 188).

SELMAN, B.J. The biology of the paropsine eucalyptus beetles of Australia. In: JOLIVET, P.H.; COX, M.L.; PETITPIERRE, E. (Ed.). Novel aspects of the biology of the Chrysomelidae. Amsterdam: Kluwer Academic, 1994. p.555-565.

SILVA, A.G. d'A. e; GONÇALVES, C.R.; GALVÃO, D.M.; GONÇALVES, A.J.L.; GOMES, J.; SILVA, M. do N.; SIMONI, L. de. Quarto catálogo dos insetos que vivem nas plantas do Brasil: seus parasitos e predadores. Rio de Janeiro: Ministério da Agricultura, 1968.

SILVA, L.D.; HIGA, A.R.; SANTOS, G.A. dos. (Coord.). Silvicultura e melhoramento genético de Eucalyptus benthamii. Curitiba: Fupef, 2012.

THU, P.Q.; DELL, B.; BURGESS, T.I. Susceptibility of 18 eucalypt species to the gall wasp Leptocybe invasa in the nursery and young plantations in Vietnam. ScienceAsia, v.35, p.113-117, 2009. DOI: 10.2306/scienceasia1513-1874.2009.35.113.

UNITED STATES DEPARTMENT OF AGRICULTURE. New pest response guidelines: Dendrolimus pine moths. Washington: USDA, APHIS, PPQ, 2012.
VILELA, E.F.; ZUCCHI, R.A. (Ed.). Pragas introduzidas no Brasil: insetos e ácaros. Piracicaba: Fealq, 2015.

WILCKEN, C.F.; BERTI FILHO, E. Vespa-da-galha do eucalipto (Leptocybe invasa) (Hymenoptera: Eulophidae): nova praga de florestas de eucalipto no Brasil. Piracicaba: Ipef, 2008. 11p.

WILCKEN, C.F.; BERTI FILHO, E.; OTTATI, A.L.T.; FIRMINO, D.C.; COUTO, E.B. do. Ocorrência de Phoracantha recurva Newman (Coleoptera: Cerambycidae) em eucalipto no Estado de São Paulo, Brasil. Scientia Forestalis, v.62, p.149-153, 2002.

WILCKEN, C.F.; FERREIRA FILHO, P.J.; LIMA, A.C.V.; ZACHÉ, B.; BARBOSA, L.R.; MASSON, M.V.; SÁ, L.A.N. de; ZANUNCIO, J.C. Introdução de Glycaspis brimblecombei e Leptocybe invasa em eucalipto no Brasil. In: SEMINÁRIO INTERNACIONAL SOBRE PRAGAS QUARENTENÁRIAS FLORESTAIS, 2012, Curitiba. Anais. Colombo: Embrapa Florestas, 2012. p.30-33.

WILCKEN, C.F.; FIRMINO-WINCKLER, D.C.; DAL POGETTO, M.H.F.A.; DIAS, T.K.R.; LIMA, A.C.V.; SÁ, L.A.N. de; FERREIRA-FILHO, P.J. Psilídeo-de-concha-do-eucalipto, Glycaspis brimblecombei Moore. In: VILELA, E.F.; ZUCCHI, R.A. (Ed.). Pragas introduzidas no Brasil: insetos e ácaros. Piracicaba: FEALQ, 2015. p.883-897.

WILCKEN, C.F.; SÁ, L.A.N.; DAL POGETTO, M.H.F. do A.; COUTO,E.B.do;FERREIRAFILHO,P.J.;FIRMINO-WINCKLER, D.C. Sistema de criação do psilídeo-de-concha Glycaspis brimblecombei (Hemiptera: Psyllidae) e de seu parasitóide Psyllaephagus bliteus (Hymenoptera: Encyrtidae) para programa de controle biológico em plantações de eucalipto. Documentos Técnicos IPEF, v.2, p.1-23, 2010a.

WILCKEN, C.F.; SOLIMAN, E.P.; SÁ, L.A.N. de; BARBOSA, L.R.; RIBEIRO DIAS, T.K.; FERREIRA-FILHO, P.J.; OLIVEIRA, R.J.R. Bronze bug Thaumastocoris peregrinus Carpintero and Dellapé (Hemiptera: Thaumastocoridae) on Eucalyptus in Brazil and its distribution. Journal of Plant Protection Research, v.50, p.201-205, 2010b. DOI: 10.2478/ v10045-010-0034-0.

WITHERS, T.M.; RAMAN, A.; BERRY, J.A. Host range and biology of Ophelimus eucalypti (Gahan) (Hym.: Eulophidae), a pest of New Zealand eucalypts. New Zealand Plant Protection, v.53, p.339-344, 2000.

ZHANG, A.-B; WANG, Z.-J.; TAN, S.-J; LI, D.-M. Monitoring the masson pine moth, Dendrolimus punctatus (Walker) (Lepidoptera: Lasiocampidae) with synthetic sex pheromone-baited traps in Qianshan County, China. Applied Entomology and Zoology, v.38, p.177-186, 2003. DOI: 10.1303/aez.2003.177.

ZÚBRIK, M.; KUNCA, A.; TURČANI, M.; VAKULA, J.; LEONTOVYC, R. Invasive and quarantine pests in forests in Slovakia. EPPO Bulletin, v.36, p.402-408, 2006. DOI: 10.1111/j. 1365-2338.2006.01025.x.

Received on August 28, 2015 and accepted on January 29, 2016

Pesq. agropec. bras., Brasília, v.51, n.5, p.397-406, maio 2016

DOI: 10.1590/S0100-204X2016000500001 